\section{LIGEIROS REPAROS À TEORIA DE DUGUIT}

\section{Darcy Azambuja}

Atualmente todos os ramos do Direito sofrem a crise que sacode - mundo moderno. As teorias, as escolas, as hipóteses vão demo lindo ou procurando demolir as grandes concepções e doutrinas clássicas, atacando-lhes os fundamentos, demonstrar a falsidade das suas conseqüências e a sua discordância com a realidade. E não há negar que, na sua atividade destruidora, quase nada deixaram de pé. Já não assim, porém, na parte construtora.

Derrubados alguns princípios, afastadas algumas idéias, o que se lhes tem procurado substituir não tem encontrado senão outras críticas igualmente destruidoras. Os autores de nossos sistemas não conseguiram obter a aprovação e a aceitação do pensamento jurídico contemporâneo. Por enquanto, estamos em plena fase de demolição, e parece que mal se delineam as primeiras nações para repor o $\mathrm{Di}$ reito em bases sólidas, teòricamente lógicas e realmente verdadeiras.

Dentre as correntes doutrinárias que iniciaram a revisão e a crítica de todo o fundamento do Direito.e das suas instituições, a do positivismo jurídico é sem dúvida a mais prestigiosa e cujos métodos têm tido mais larga difusão, e o mais ilustre representante do positivismo jurídico foi sem dúvida Léon Duguit. As suas teorias, ou melhor, as críticas por êle feitas à concepção tradicional do direito e do seu fundamento, à concepção do Estado, e da soberania, lograram uma repercussão universal. E, exatamente por que propôs uma nova teoria do direito, os seus pontos de vista repercutem em todos os setores da ciência jurídica, desde o direito civil ao direito internacional. Não há hoje uma obra de caráter geral sôbre o direito que não exponha e adote ou combata as teorias do eminente jurista francês. Após a sua morte, em setembro de 1928, as publicações especiais feitas in memoriam demonstraram a larga e funda influência que a sua poderosa inteligência exercera em tôda a atividade intelectual de seus contemporâneos.

Duguit, propondo manter-se rigorosamente no domínio dos fatos e rejeitar todo e qualquer princípio teórico ou metafísico, procurou através da sociologia, o fundamento positivo e real do direito.

Como Descartes, fêz tábua rasa de tôdas as concepções e doutrinas anteriores, e foi buscar na observação objetiva dos fatos sociais a gênese das normas jurídicas.

A observação direta, diz Duguit, fornece-nos de início dois fatos fundamentais, que ninguém poderia contestar: primeiramente, o homem é um ser consciente de seus atos; em segundo lugar, é um ser social, que sempre viveu em sociedade e que não pode viver senão em sociedade. Dêsses dois fatos, objetivamente observados, decorre outro igualmente inegável: a lei social ou norma social. Se o homem não pode viver senão em sociedade e é um ser consciente de seus atos, necessàriamente tem que subordinar a sua atividade à existência da sociedade. A norma social obriga o indivíduo a colaborar na ordem social, isto é, a fazer tudo que pode para manter a sociedade e não fazer nada que possa destruí-la. E tudo isso porque, sendo os homens sêres sociais, mas com aptidões diversas e necessidades comuns, têm todos necessidade de trocar serviços, de se auxiliar mùtuamente, para sobreviver e para que a sociedade perdure: é a solidariedade, a grande lei que rege as sociedades humanas. A sociedade não poderia subsistir se a conduta de cada indivíduo fôsse absolutamente nociva e por isso êle tem de subordinar o interêsse pessoal ao interêsse coletivo, ao interêsse do grupo. A experiência da bondade de certos atos e da nocividade de outros para o convívio social, a consciência dêsses atos, a memória e a hereditariedade concorrem para formar, em cada grupo, hábitos e costumes, que se fixam como normas de vida, cuja violação, acarretando prejuízos à coletividade, é censurada, reprimida, punida. O homem, ser inteligente e consciente, é eminentemente apto para fixar e prever as limitações à sua atividade impostas pelo interêsse coletivo. A observância da conduta favorável à sociedade, a norma social que traduz essa conduta, forma-se primeiro na consciência individual, transmite-se de geração em geração, fixa-se na tradição, que é a memória coletiva, e se torna por fim psicològicamente obrigatória. Essas normas não têm o mesmo grau de rigor e obrigatoriedade, não acarretam tôdas as mesmas reações. As normas sociais são unas pelo seu fundamento e objeto, mas são complexas e diversas pela intensidade das reações que provocam; elas compreendem um conjunto de normas econômicas, morais e jurídicas. Tanto as normas econômicas como as normas morais são necessárias à coesão do grupo e a sua transgressão determina uma reação. As normas jurídicas, são as que provocam uma reação mais íntima, por serem julgadas mais importantes para a existência do agregado social. A transgressão de uma norma econômica ou moral é reprovada por todos ou quase todos os membros do grupo, mas a transgressão da norma jurídica, que é considerada vital, tem uma reação social mais intensa e enérgica, e é isso ùnicamente o que a distingue das outras normas. Não há diferença de fundamento, de 
conteúdo entre as normas sociais em geral e a norma jurídica; o que as distinguem é apenas a reação que provocam, é a opinião que o grupo tem sôbre a importância de cada uma. Uma regra moral ou econômica pode ser durante muito tempo de importância secundária para um grupo social, mas em dado momento, por fôrça de condições novas de vida social, tornar-se de importância essencial e transformar-se então em norma jurídica.

"Os mesmos atos, diz Duguit, inteiramente individuais, como a hora da refeição, a quantidade e a qualidade dos alimentos a serem absorvidos, o tempo de repouso, podem tornar-se, em certas circunstâncias, como durante uma guerra, objeto de prescrições legais severas".

Assim, com as próprias palavras do eminente jurista, uma norma social qualquer se torna norma jurídica no momento em que a massa dos espíritos tem o sentimento de que o respeito dessa regra é essencial à solidariedade social e que ela reclama a sanção organizada da autoridade, do Estado, enfim.

Assim procurou Duguit, baseado puramente na observação dos fatos sociais, e jogando exclusivamente com fatos, determinar a origem e formação do direito.

Mas, terá êle realmente ficado sempre no terreno dos fatos, e na verdade fornecido um quadro exato da gênese da regra jurídica?

Admitida; sem esfôrço, a existência da regra social, não é fácil no entanto apreender o modo e o momento pelos quais as regras sociais se transformam em regras jurídicas. Que vem a ser exatamente essa "massa dos espíritos", essa "massa das consciências" individuais que Duguit erigiu em órgão declarador do direito? Não admitindo êle a existência de uma vontade coletiva também não quis admitir uma consciência coletiva. Assim essa massa das consciências individuais deve ser a maioria, a opinião da maioria dos indiví duos do grupo. $\mathrm{Na}$ sua concepção, portanto, a regra jurídica, o direito, é constituído por aquelas normas sociais que em um determinado grupo, em momento dado, a opinião da maioria considera como devendo ser coativamente obrigatórias. Se a isso Duguit chamasse sòmente lei ainda bem; mas denominar Direito o que a opinião da maioria dos membros de um grupo social, em um momento passageiro, considera importante, essencial para a vida dêsse grupo, é reduzir a bem pouco o direito. Nenhum princípio superior, nenhuma regra permanente, apenas a opinião da massa das consciências individuais.

Mesmo porém, que se admita êsse processo quase mecânico, e puramente psicológico, de produção do Direito, veremos se o positivismo jurídico resolve as dúvidas e dificuldades mais importantes.

Em primeiro lugar, como saber, como reconhecer que em certo momento uma determinada regra social é considerada essencial pela massa das consciências individuais? Em um grande grupo social,

cujos membros se contem por milhões, como acontece em quase todos os Estados modernos, quais os meios de verificar que a massa das consciências individuais tem esta ou aquela opinião? Quem são os órgãos autorizados para exprimir essa opinião? Os parlamentos, os órgãos legislativos? Duguit responde que não. Em sua doutrina, os parlamentos não são órgãos de representação da vontade coletiva, até mesmo por que a vontade coletiva não existe. Neste impasse pondera Duguit que ao legislador e ao jurista cumpre sondar a opinião da massa, procurar descobrir e fixar a orientação das opiniões individuais e apurar se formam a maioria.

$E^{\prime}$ bem complexo, delicado e arbitrário mesmo êsse processo, em que ao legislador e ao jurista, sem o socorro de nenhum princípio coutrinário, sem a base de nenhuma regra ideal e imutável de justiça, cumpre mergulhar no oceano das consciências individuais para auscultar-lhes a direção e conferir-lhes o número. Será possível essa tarefa? Será possível reduzir o Direito à opinião da maioria e será possível auscultar em cada caso a opinião dessa maioria? Suponhamos que sim, que o legislador e o jurista devem e podem auscultar concretamente essa opinião. Que acontecerá?

Na maioria dos casos não existirá opinião. A massa das consciências individuais desinteressa-se, não conhece ou não ligou importância à questão. Em outros casos, a natureza da questão, o objeto da regra social é de tal mọdo complexo que a massa das consciências não o apreende, não o compreende. Sempre que se tratar de assuntos técnicos, especializados, isso se dará. Só uma reduzida minoria poderá ter opinião segura sôbre a maioria das questões complexas que se tratem de resolver. Nos próprios parlamentos são poucos os que têm conhecimentos suficientemente gerais e profundos para decidir com clareza sôbre a maioria dos projetos discutidos.

Que dizer, pois, da massa social, onde a ausência de cultura e a luta pela vida não permitem estudar e formar opinião sôbre todos os assuntos que são objeto de legislação.

Suponhamos, no entanto, que se trate de auscultar a opinião sôbre um assunto concreto, que interesse realmente a todos, que seja assaz simples para que qualquer indivíduo tenha opinião sôbre êle. Há assuntos que apaixonam e interessam profundamente a sociedade, a qual se pronuncia por vários meios, notadamente pela imprensa. Será fácil, nesses momentos, perceber e verificar a opinião da maioria? De modo algum. $\mathrm{O}$ que geralmente acontece é que não exista realmente maioria de opinião, é que a opinião pública se divida e subdivida em tantas direções e alvitres diferentes e contraditórios que será impossível estabelecer sequer a média das preferências. Quanto mais o assunto interessar o público, tanto maiores serão as divergências, e geralmente os grupos que mais ruído lançam serão os de alvitre menos conforme ao interêsse social. Salvo casos raros e excepcionais, 
em que se forma realmente uma grande corrente num sentido determinado, o que o legislador e o jurista encontram, nessa sondagem do ambiente social, não é uma opinião pública, e sim manifestações variadíssimas de grupos de opinião, em tumulto de alvitres e preferências inconciliáveis, onde os interêsses se entrechocam e onde se torna impossível encontrar sequer a tolerância, quanto mais uma regra de justiça aceita por todos.

Assim, o conceito de Direito apresentado por Duguit, além de reduzir o Direito à simples opinião variável de maiorias efêmeras, é na realidade impossível de apreender e apurar. Procurando reduzi-lo a um simples fato, Duguit tornou o Direito irrealizável, incompreensível e mais fugaz do que nos mais abstratos sistemas filosóficos.

Não foi mais feliz o outro eminente reformador da escola de Viena, Hans Kelsen, que identificou o Estado com o Direito, tornando êste a mera lei escrita, a vontade dos que executam as funções de govêrno.

Por isso mesmo, a atividade da escola do positivismo jurídico tem sido sòmente destrutura, e se a análise percuciente, a crítica serena que fêz de algumas concepções tradicionais conseguiu desprestigiar e destruir muitos princípios até agora admitidos, não conseguiu, porém, substituí-los por outros princípios mais sólidos. Destruiu, mas não pôde construir, e daí a instabilidade e a confusão que desorientam o pensamento moderno.

Mas, o equilíbrio já se vai restabelecendo. Passada a primeira fase de tumulto e perplexidade, os juristas e filósofos, sem desprezar o que houve de verdadeiro no positivismo jurídico, vão restabelecendo em bases seguras os grandes princípios sôbre que repousava o Direito. Mesmo entre os que se mantêm fiéis ao método e ao objetivo da escola positivista, volta-se a compreender que o homem não se resume no seu organismo fisiológico, que o direito, se é uma norma social, não tira a sua legitimidade dos fatos materiais da coexistência e da solidariedade nos grupos; que acima dos fatos e dos interêsses, superior muitas vêzes ao próprio interêsse coletivo do momento, há princípios e idéias que o homem procura atingir e aos quais pede a causa legítima das suas ações. Volta-se, enfim, a compreender que êsses ideais e êsses princípios, se bem que nunca atingidos e freqüentemente negados, são uma realidade também, uma necessidade imutável do espírito humano.

E hoje, com exceção de raros sectários do materialismo histórico, já em decadência, juristas e filósofos estão acordes em reconhecer que o direito é filho da moral e da razão, que será sempre necessário um ou alguns princípios morais como regra suprema a que se devem conformar tôdas as regras jurídicas.

Estabelecido êsse consenso preliminar, não era difícil prever o início de uma fecunda corrente que procuraria reconstruir a ciência

jurídica conforme a princípios permanentes, a ideais verdadeiramente humanos.

Quais, porém, os princípios morais, perguntar-se-á, aceitos por todos, que servirão de base e fundamento para o Direito? Os sistemas de moral são ainda mais numerosos e variados do que as teorias e filosofias do direito. Na moral também a instabilidade e a diversidade das teorias, a variação e flutuação dos meios sociais se fazem sentir. Já Pascal dizia que a moral varia com os meridianos e as latitudes.

Essa própria diversidade, porém, obrigaria os juristas a encontrar uma direção comum. Nenhum filósofo, nenhum sistema de moral tem conseguido sequer aceitação para os seus princípios em um grupo social mais ou menos numeroso. Os sistemas de moral até aqui elaborados não passam de construções teóricas sem influência sôbre os espíritos. Mas, ninguém negará que há uma moral que tem inspirado tôda a nossa civilização: a moral cristã. Mesmo os que não professam a religião de que ela faz parte, não contestam a pureza de seus preceitos, nem negam que ela tem sido e é ainda a única moral que pode merecer o título de universal. A pobreza, a inanidade, a inexistência mesmo de outra moral, tornam ainda mais sólida e geral a moral cristã.

Sobretudo, como bem disse um jurista contemporâneo, a moral de Cristo não é nem sôbre-humana nem inumana, mas profundamente humana, a que mais de perto fala ao coração dos humanos, a que melhor se adata à sociedade atual, que aliás se construiu com ela e sôbre ela. E' uma moral equilibrada, que leva em conta todos os fatôres naturais e, ainda que apontando ao homem um ideal puríssimo e só atingível pelas individualidades excepcionais, não o intimida nem desanima, mas ministra-lhe todos os recursos necessários para uma conduta social digna em relação a si mesmo e benéfica em relação aos demais.

Todos os grandes princípios morais de fraternidade, igualdade ssistência entre os homens são ensinamentos da moral cristã. Ninguém a ataca como moral; os que dela divergem o fazem pelo seu conteúdo religioso, mas os próprios materialistas não lhe negam a pureza e humanidade dos princípios.

O próprio Duguit, o pontífice máximo do positivismo jurídico, assim se pronunciou, em seu Tratado de Direito Constitucional:

"Se me é permitido fazer uma incursão no domínio religioso, direi que só mitos cristãos puderam fazer penetrar na alma humana a concepção fundamental de todo o ideal humano e de tôda a civilização, "e que não houve verdadeiramente civilização senão depois do cristianismo e em conseqüência do cristianismo, pois só êle fêzz compreender que o homem não é homem e não tem valor senão pelos 
laços que o unem aos outros homens, aos vivos e aos mortos, pelo culto que dedica aos mortos pelos serviços que presta aos vivos. Não digo isso como crente, mas como sociólogo, profundamente respeitoso por tôdas as crenças sinceras, mas que se presume liberto de todo o dogma e de todo o preconceito".

Essas palavras leais de Duguit parece terem frutificado. 0 tratados recentes sôbre filosofia do direito e sôbre direito público, onde o conceito de direito natural revive purificado das deformações que sofrera, estão impregnados das idéias e dos princípios que inspiraram os grandes sistemas jurídico-morais de Sto. Tomaz de Aquino e Sto. Agostinho, de Belarmino e Suarez.

$\mathrm{E}$ é de esperar que o século $\mathrm{XX}$, mau-grado os momentos tumultuosos que o mundo atravessa, restaurará a obra demolida pelo racionalismo do século XVIII e pelo materialismo do século XIX.

O Direito, repôsto sôbre bases perenes, inspirado por princípios morais universais, não será um instrumento de luta e de opressão, mas uma norma de justiça, de paz e de fraternidade entre os homens.

\section{O JÚRI E A SUA COMPETÊNCIA FIXADA PELA CONSTITUIÇÃO}

\section{José Salgado Martins}

Ainda se controverte a competência do júri, instituída obrigatòriamente pela Constituição Federal, art. 141, § 28, no que tange "aos crimes dolosos contra a vida".

Desde a discussão no Senado, apresentado o projeto $n .^{\circ} 1$, de autoria do ilustre senador Olavo Oliveira, que se constituíram duas correntes, no sentido de interpretar o texto constitucional.

O projeto do senador Olavo Oliveira, objetivando conciliar a lei ordinária com a lei magna da República, fixava a competência do júri relativamente a "todos os crimes dolosos, de qualquer espécie, de cuja prática resulte morte, seja qual fôr a sua capitulação".

O substitutivo, apresentado a êsse projeto pela Comissão de Constituição e Justiça do Senado, reduzia a competência ao julgamento dos crimes definidos pelo Código Penal de 1940, no Capítulo I do Tí́tulo I, sob a denominação de "crimes contra a vida".

Essa, orientação prevaleceu, afinal, e assim dispõe a Lei n. ${ }^{\circ} 263$ de 23 de fevereiro de 1948, que, modificando dispositivos do Código de Processo Penal, teve em mira afeiçoar a instituição do júri aos. princípios adotados pelo Estatuto Fundamental da República.

Sem embargo da lei ordinária haver se inclinado pela interpretação restritiva da competência do júri, a controvérsia não se encerrou; pois, na jurisprudência e na doutrina, surgem autorizadas opiniões que reivindicam para o júri a ampla competência que, obrigatòriamente, the deferiu a Constituição Federal, no tocante a todos os crimes dolosos de que resulte morte, seja êste evento querido pelo agente, ou seja conseqüência do simples risco assumido, através da prática de antecedente crime doloso.

A tese envolve matéria de alta relevância.

Cumpre examinar os argumentos em que se apóiam as correntes em luta e dêles inferir à qual delas cabe a procedência e a harmonia com o texto constitucional, a que deverá ceder o passo a lei ordinária.

$\mathrm{O}$ projeto n. $^{\circ} 1$, de autoria do senador Olavo Oliveira, professor catedrático de Direito Penal da Faculdade do Ceará, dispunha no artigo $2 .^{\circ}$ : 